\title{
CD86 Positive
}

National Cancer Institute

\section{Source}

National Cancer Institute. CD86 Positive. NCI Thesaurus. Code C150472.

An indication that expression of CD86 has been detected in a sample. 